\title{
The path to extreme violence: Nazism and serial killers
}

\author{
Philippe Cotter* \\ Geneva International Academic Network, Geneva, Switzerland
}

Edited by:

Guillaume Poirier, Ecole Polytechnique

Federale de Lausanne, Switzerland

Reviewed by:

Albert Rizzo, Institute for Creative

Technologies, USA; Mark Levine,

Lancaster University, UK

*Correspondence:

Philippe Cotter, Rue du Vieux-Billard 9,

1205 Genève, Switzerland.

e-mail:pcotter@bluewin.ch
In people's minds, extreme violence is an enigma. The tortures inflicted on defenceless victims seem to defy reason. Yet, the fact that these incidents keep recurring is proof that there are rules governing them. It is these rules that I have attempted to isolate. We shall see that they are clearly defined and that they are to be found in individual as well as collective violence. To categorise them is the first step towards implementing preventative measures which would help to protect the rational majority from a dangerous minority. Practice and theory are inextricably linked in the analysis of "organised insanity" that is extreme violence.

Keywords: extreme violence, psychohistory, authoritarian personality, psychopathy, trigger event

\section{INTRODUCTION}

I would like to explain briefly how this research started. Initially, in the mid-1990s, while I was doing my $\mathrm{PhD}$ at the Graduate Institute of International Studies in Geneva, it was going to focus exclusively on collective violence and would remain within the parameters of traditional historical analysis. Subsequently however, intellectual curiosity incited me to look at other forms of extreme violence, in individuals this time, and more specifically in serial killers. To my great surprise (this had never been studied), it emerged that there were a number of similarities between the psychology of the serial killer and that of political extremists, the Nazi leaders in particular. Visibly, the field of study would have to be extended to encompass these findings, making use of all relevant scientific disciplines.

\section{SOURCES}

\section{PSYCHOHISTORY}

Ever since the end of the Second World War, Hitler and the main Nazi leaders have defied the scientific community: how does one explain the psychology of politicians responsible for the worst atrocities and showing no remorse for their actions? Psychohistory, the discipline that combines psychology and history, posited the existence of a direct correlation between the intensity of the Nazi extremists' psychological disturbances and the intensity of their cruelty (Friedländer, 1978). But such a model cannot be generalised. Many patients suffering from severe mental disorders do not show any sign of violence towards their environment.

Consequently, I put forward the hypothesis that the intensity of the mental health disturbances of any individual resorting to extreme violence is merely indicative of the socialisation of the violence used (Cotter, 2006). In this model, political crime, as represented by Hitler and other Nazi leaders, is associated with low intensity psychological problems (Browning, 1992). Suffering from mild symptoms, Nazi extremists were able to rationalise extreme violence and construct an ideology, disseminated amongst members of targeted groups. On the other hand, in contact crime (where there is physical contact between aggressor and victim, e.g. serial killers), individuals are affected by psychological disorders so severe that they are incapable of building a complex Weltanschauung (a theory of the world) (Jäckel, 1972) to vindicate their use of violence.

\section{THE AUTHORITARIAN PERSONALITY}

In the review of references consulted, the study on the authoritarian personality by Theodor Adorno, Else Frenkel-Brunswick, Daniel Levinson and Nevitt Sanford, published in 1950, must be mentioned in second place (Adorno et al., 1969). The Berkeley group arrived at the conclusion that there are certain characteristics common to every person receptive to fascist propaganda. These people, it was postulated, must have the same mental structure, described as ethnocentric and prone to prejudice. The authoritarian mental structure is contrasted with the liberal one, which is defined by the opposite characteristics, i.e. non-ethnocentric, unprejudiced and unreceptive to fascist propaganda.

\section{PSYCHOPATHY}

In 1941, a few years before the publication of the Berkeley group's findings, American psychologist Hervey Cleckley had given a detailed listing of the characteristics of the psychopath, the most striking of these being the lack of remorse in the use of cruelty (Cleckley, 1988). A psychopath has a very egocentric view of the world and distorts reality in order to justify his actions. Following in Hervey Cleckley's footsteps, Robert Hare compiled in the 1980s a list of twenty indicators identifying psychopaths and measuring the intensity of their symptoms (Hare, 1991). It will become apparent below that both concepts - Hervey Cleckley's psychopathy and the Berkeley group's authoritarian personality as seen above - are combined in the psychopathic aggressor, the personality type common to all forms of extreme violence.

\section{FBI RESEARCH}

In the 1970s and 1980s, several FBI agents (the celebrated profilers) carried out research on murderers acting repeatedly and in isolation, without any apparent ideological motivation. They split them into two categories: organised serial killers, who plan the execution of each crime, and disorganised serial killers, who act on impulse and are incapable of controlling their actions (Hazelwood and Douglas, 1980). Both groups are characterised by a total lack of remorse towards their victims, and by their disregard for material gain: they are not seeking financial benefit, but look only to obtain some degree of emotional satisfaction. 
The explanations developed so far can be used to start answering the questions surrounding the serial killer's enigmatic behaviour. We know, from the absence of ideological framework, that he suffers from acute psychological disturbances which prevent him from socialising his violence, unlike political criminals, such as the Nazi leaders. These intense difficulties constitute the first level of a serial killer's mental structure. On the second level, organising the chaos, is a rigid authoritarian personality which enables him to find emotional compensation for his internal disorders through violence. It is easy to understand that such a mental structure, in itself complex, would take years to develop, in most cases from childhood, as FBI agent Robert Ressler remarked: "Let me state unequivocally that there is no such thing as the person who at age thirty-five suddenly changes from being perfectly normal and erupts into totally evil, disruptive, murderous behaviour. The behaviours that are precursors to murder have been present and developing in that person's life for a long, long time - since childhood." (Ressler and Schachtman, 1992, p. 116).

\section{THE PSYCHOPATHIC AGGRESSOR}

In this second section, I shall examine the authoritarian syndrome which, combined with psychopathic traits and psychological disturbances, makes it possible for offenders to turn to extreme violence. The psychopathic aggressor has the following characteristics (Cotter, 2007):

1. Egocentricity. The psychopathic aggressor strongly denigrates his victims in order to inflate his self-esteem.

2. Cruelty. Cruelty is used by the psychopathic aggressor to force his victims to submit to him. This process intensifies the feeling of omnipotence he experiences as a result of his egocentricity.

3. Lack of remorse. The psychopathic aggressor expresses no remorse for the violence inflicted on his victims. On the contrary, a victim's suffering is proof of his dominant position and serves to increase the internal stimulation he seeks as compensation for his emotional inadequacies.

4. Social polarisation. The psychopathic aggressor's Weltanschauung is characterised by the idealisation of his reference groups and the denigration of stigmatised communities perceived as a threat. This Manichean socialisation reaches its full measure with the political criminal, whereas it remains at an embryonic stage with the serial killer, hindered by the intensity of his underlying psychological disturbances.

At this stage it is possible to organise our analysis of the inner world of the psychopathic aggressor in chronological sequence. The development of the authoritarian syndrome is as follows:

1. Appearance of emotional disturbances.

2. The psychopathic aggressor offsets his emotional conflicts with the authoritarian syndrome. A position of objective inferiority in everyday life is thus transformed into a position of power.

3. Authoritarianism causes a process of mental degeneration in the psychopathic aggressor which will be analysed in the next section.
4. When the development of the authoritarian syndrome is complete, the psychopathic aggressor implodes under the powerful dynamics created and loses touch with reality (see next section).

When do the first signs of the authoritarian syndrome appear? As long as a child is not capable of distinguishing in-group and outgroup categories, he does not possess the analytical tools required for social polarisation and authoritarianism is too complex for him. Emotional conflicts in early childhood are therefore "pure," i.e. non-violent, because devoid of any authoritarian dimension. It is only when newly acquired skills make him able to discern social diversity in his environment that the troubled child finds an egocentric alternative to his frustrations, that of authoritarianism (Tajfel, 1969).

In adults, authoritarian symptoms are generally limited to a subdued version I refer to as conflictual empathy, particularly in family and professional circles (Hirigoyen, 2000). Extreme authoritarianism, in the shape of a fully developed syndrome, occurs only in the most dangerous aggressors, whether acting alone (contact crime) or collectively (political crime).

\section{PSYCHOPATHIC PARANOIA}

To fully understand extreme violence, it is necessary now to delve into the recesses of the mind, where anxieties originate, and see how psychopathic aggressors organise their internal reality.

Two types of anxieties allow us to adapt to our social environment. Paranoid anxieties protect our own integrity. Depressive anxieties (remorse) deter us from behaviours potentially detrimental to others, thus ensuring we receive support from them in times of adversity (Klein, 1992). This dual, emotional, set of anxieties presents the psychopathic aggressor with a complex problem when he commits acts of violence: every time he uses extreme force on his victims he risks being overwhelmed by paranoid and depressive anxieties. To avoid this, he has to develop denial systems that will eliminate any uncertainty.

The psychopathic aggressor uses justification, the first authoritarian denial mechanism, to proclaim the benefits of his violence. Justification inhibits any feelings of remorse by destroying depressive anxieties. This first level of cognitive distortion is particularly apparent in sexual aggressors, who justify their acts despite the obvious flaws in their reasoning (Marshall, 1999). If justification is the first psychological strategy used by the psychopathic aggressor, it is not, however, the end of the process. In order to organise his internal reality, the psychopathic aggressor resorts to a second cognitive distortion: victim blame, whereby his victims are blamed for bringing upon themselves the violence they suffer (Cleckley, 1988). Victim blame is balanced by role reversal: the psychopathic aggressor poses himself as the victim of the individual or the group he is attacking. Victim blame and role reversal are clever strategies as they shift the burden of responsibility onto the victims of violence; continuing in this line of reasoning, the victims' own behaviour is the cause of their suffering (Cotter, 2007).

Historian Omer Bartov underlined the crucial part played by victim blame and role reversal during the massacres conducted by German soldiers in the Soviet Union during the Second World War (Bartov, 1991). "The Jew is not the victim, he is the aggressor," wrote 
Hitler in Mein Kampf, almost twenty years before the Holocaust (Hitler, 1933, p. 355). In a striking parallel, psychologist Howard Barbaree highlighted the importance of victim blame and role reversal in the most serious sexual crimes (Barbaree, 1993). Thus the rapist, when arrested, will believe he is being unfairly accused because in his view the victim was purposely provoking him and the suffering she endured was only what she deserved.

In view of the identical thought patterns found in all types of extreme violence criminologist Stanton Samenow concluded: "Despite a multitude of differences in their backgrounds and crime patterns, criminals are alike in one way: how they think." (Samenow, 1984, p. 20).

Having highlighted the purpose of justification, victim blame and role reversal in the authoritarian rationalisation systems, there is still one question to be answered - a deceptively easy question that, in fact, necessitates complex developments: who is right, the psychopathic aggressor, defending his guilt-inhibiting theories, or his victims who refute them? To answer this question it is necessary to highlight the dynamics associated with the different cognitive processes outlined above. Their relevance or otherwise will then become clear.

For all their complexity, the mechanisms of justification, victim blame and role reversal are flawed. Victim blame and role reversal are patently counterproductive. Not only does the role shift from aggressor to victim fail to appease the psychopathic aggressor's anxieties, it actually increases his paranoia since he feels permanently under threat. Furthermore, his depressive anxieties only appear to be eliminated. Guilt and remorse cannot be destroyed, as they are fundamental to the functioning of the mind. They are simply stripped of their symbolic, altruistic content, i.e. transformed into paranoid anxieties which are asymbolic by nature (Cotter, 2007).

The psychopathic aggressor cannot escape the downward spiral when the depressive anxieties he is trying to rid himself of are transformed into asymbolic anxieties, which in turn reinforce his paranoid symptoms. There is a further development: the authoritarian syndrome presents a dynamic process of self-destruction. The psychopathic aggressor's artificial increase in paranoid anxieties triggers an even greater need to resort to justification, victim blame and role reversal during his repeated aggressions, causing irreversible cognitive distortions. Once the cycle has begun, paranoid anxieties and denial strategies interact in an increasingly radical manner, imprisoning the individual in a simplistic and egocentric view of the world which gradually loses any power of adaptability. This mental deterioration has been observed in contact criminals (serial killer Ted Bundy) (Keppel and Birnes, 1995) as well as in political criminals (Hitler, Stalin) (Speer, 1969; Suny, 1997).

Reverting to the question asked above (who is right, the psychopathic aggressor or his victim?) there can be no doubt as to how to answer it: the powerful dynamics of cognitive and paranoid degeneration the psychopathic aggressor is caught up in is proof that the denial mechanisms he resorts to are inadequate. However defiant his attitude, he is, in the end, always defeated by the forces he himself has unleashed. Martin Luther King once wrote that "evil contains the seed of its own destruction." (King, 1986, p. 506).

\section{SELECTIVITY}

Extreme violence in individuals results from the interaction between psychological disorders and authoritarian symptoms, as we have already seen. Eugen Kogon, who spent several years in detention in Nazi camps, made in 1947 the following distinction: "The men who volunteered for Hitler's elite guards were almost without exception of a type in whom a primitive psychological mechanism was at work. Their minds were enclosed by a hard shell consisting of a few sharply fixed, dogmatic, simplified concepts, underneath which lurked a flood of inchoate emotionalism. The only form of soulsearching to which they submitted amounted to no more than a checkup as to whether the direction of their emotions actually corresponded to the prescribed SS goals." (Kogon, 2006, p. 283).

This excerpt shows with clarity the crux, and maybe even the secret, of extreme violence: selectivity, which shapes the link between an aggressor's psychological disturbances and his authoritarian symptoms. The perpetrator of extreme violence structures his mind in such a way that his "flood of inchoate emotionalism" is released in violent outbursts, following pre-determined directions. Because the violence is carefully targeted at selected victims, the aggressor protects himself from his authoritarian symptoms, whilst at the same time keeping a stable, empathic relationship with the part of reality which is preserved from his attacks. He thus becomes a functional paranoiac, as FBI agent John Douglas put it (Douglas and Olshaker, 1999).

\section{PSYCHOPATHIC NEUROSIS}

Following the developments in the previous section on the selectivity of authoritarianism, we can now add a new category to traditional psychopathological classifications: psychopathic neurosis is a separate clinical entity resulting from a dual distortion - both neurotic and authoritarian (Cotter, 2007). This disorder is more serious than ordinary "non-violent neuroses" (or "non-violent psychosis"), which consist of psychological disturbances on their own, without any authoritarian extension. As for the aetiology (cause) of psychopathic neurosis, it is based on a set of primary pathogenic factors, responsible for neurotic disorders, and a set of secondary pathogenic factors, producing authoritarian symptoms (Friedländer, 1947).

Analytical therapies, such as psychoanalysis, are of little use in treating psychopathic neurosis because of the dual distortion at play. These therapies address only the primary, non-violent symptoms and are unable to modify the secondary, authoritarian symptoms. Detention likewise has no effect. The psychopathic aggressor incorporates this punishment into his egocentric rationalisations whereby he sees himself as a victim who is being treated unfairly. Only the appearance of remorse for the acts committed and of empathy with the victims would signal a potential for remission. This type of evolution, however, is not attractive for the psychopathic aggressor because violence compensates for his psychological disorders. To renounce authoritarianism would also mean having to deal with massive remorse - particularly if the suffering inflicted on victims was intense (Suedfeld and Landon, 1978).

The above considerations emphasise the need for effective protection of the community: in cases of extreme violence, the chances of remission are slim and, consequently, in the event of release, the risk of re-offending is high (Hare et al., 1992). If the processes 
of authoritarianism are not yet structured, the psychopathic aggressor's mental apparatus can lend itself to re-organisation (Moffit, 1993). This implies, however, as Peter Suedfeld and Bruce Landon remarked, that "therapy works best with those who need it least." (Suedfeld and Landon, 1978, p. 369) Detention presents a similar dilemma: it works best with the less dangerous individuals, who are still able to feel remorse for the suffering inflicted and who are willing to adapt to the rules of social life.

\section{THE PATH TO EXTREME VIOLENCE}

In the following section we shall see that early warning signs are a feature of individual as well as collective violence and, if heeded, could be used for preventative action. We shall also see that the lengthy development which leads a potential criminal to extreme violence bears many similarities with the process enabling a small group of criminals to implicate whole communities in acts of genocide.

The dynamics that lead a serial killer to a first act of murder develop over a long period of time. I have identified five stages in this process, namely (Cotter, 2007):

1. Emotional problems

2. Initiation

3. Adaptation to murder

4. Trigger event

5. Act of murder

The serial killer's extreme violence, based on domination and coercion, is a form of compensation for severe emotional problems. When does an individual become aware of the potential of this compensation mechanism? It happens very early on, in childhood. FBI research into the origins of violence in the most dangerous criminals emphasises the early onset of this initiation stage (Ressler et al., 1992). The troubled, socially isolated child, who develops a taste for the thrill experienced whilst engaging in deviant behaviour, will use his intellectual abilities to construct egocentric alternatives which serve to offset the low level of satisfaction derived from everyday social interaction (Douglas and Olshaker, 1999).

Having discovered that authoritarian behaviour can compensate for lack of social skills the "apprentice murderer" sets out on a long path which will gradually put in place the fantasies and systems of self-justification allowing him to act. The trigger event is usually a negative episode in everyday life (financial problems, loss of a job, break up of a relationship) which has the effect of throwing the potential murderer off balance. He plunges into extreme violence and seeks refuge in the exultation brought on by the knowledge that he has absolute power over his defenceless victims (Ressler and Schachtman, 1992).

The dynamics that lead a serial killer to a first act of murder develop over a long period of time. The same applies to collective atrocities (Staub, 1989). What marks the progression towards genocide? It is always a gradual radicalisation process and consists in a series of incontrovertible stages, as detailed below (Cotter, 2007):

1. Social brutalisation. At this first stage a crisis-ridden society is confronted with a multitude of economic, political and ideological difficulties which create extreme social tensions, making individuals more tolerant of acts of brutality (Mosse, 1990).
2. Fascist consensus. Social brutalisation leads to an alliance between extremists, whose violence is presented as a solution to problems, and the masses who accept them in the hope of restoring cohesion. Once in power, the extremists impose dictatorship (Kershaw, 1987; Fromm, 1991).

3. Trigger event. Last stage in the process culminating in genocide, a trigger event occurs (as is the case for serial killers) that precipitates systematic mass murder. This usually takes the form of military defeat: in Nazi Germany genocide came in the wake of the first military setbacks of the Russian campaign. The tipping point happened in the summer of 1941, when the Nazi leaders became aware that they no longer had the upper hand in the Second World War and that their despotic authority was weakening. Genocide was a means of reasserting their power by targeting a defenceless group whom they blamed for all their difficulties (Burrin, 1994).

Other twentieth century collective atrocities had similar trigger events. In Cambodia, genocide began when the Khmer Rouge suffered several military defeats against Vietnam (Kiernan, 2002). The Armenian genocide got underway when the Ottoman Empire was humiliated by Russia during the First World War (Akçam, 2004). The trigger event in the genocide of the Rwandan Tutsis was rather paradoxically the 1993 Arusha (Tanzania) peace talks when the extremists in power realised that the agreements would force them to make major concessions. They began planning genocide as a means of reasserting their absolutism by attacking defenceless victims (Human Rights Watch, 1999).

\section{CONCLUSION: EARLY PREVENTION}

Early warning signs, in the long process leading to atrocities, are a feature of collective as well as individual violence. If heeded, they could be used for preventative action before dysfunctional emotional patterns and resentment have had a chance to turn into authoritarian traits (Jaffé, 2008). Early prevention consists in swift intervention that will give humiliation-ridden individuals or groups the tools to develop resilience, and thus avoid negative alternatives (Gilligan, 2001).

What can we do to encourage resilience and reduce the risk of acts of violence? Extensive research carried out by the University of Minnesota found that children exposed to multiple risk factors were more likely to suffer psychological and developmental problems. Five types of risk were taken into account over a period of 15 years: child maltreatment, inter-parental violence, family disruption, low socioeconomic status and high parental stress (Appleyard et al., 2005). According to this study, one risk factor on its own, even severe, has little impact on a child's capacity for resilience and does not greatly affect development. Children thus exposed tend to summon up the strength to overcome a temporary crisis. When confronted with several risk factors, however, even at moderate intensity, they find it much harder to cope because of the cumulative effect of such problems and the generalised disorderliness of their environment.

The multiple risk theory has the merit of pointing in new directions as far as early prevention of violence is concerned, for as the University of Minnesota researchers remarked, "reducing any one risk is important". Thus by lowering, even slightly, the impact of 
multidimensional difficulties, the child's capacity for resilience can be stimulated (Rutter, 1990). Any intervention would thus take place before psychological disturbances had mutated into selectivity and potentially violent behaviour (Negrao et al., 2008).

This observation is also valid for groups. In times of crisis, social risk factors (financial difficulties, political troubles, inequalities, turmoil on the international scene amongst others) are manageable one at a time. Once they start to cumulate, their potential for destabilisation increases, and the ensuing feelings of collective humiliation impel demoralised populations to form alliances with fanatical extremists (Moïsi, 2007). The first step in elaborating strategies for the early detection of collective violence is therefore

\section{REFERENCES}

Adorno, T., Frenkel-Brunswik, E., Levinson, D., and Sanford, N. (1969). The Authoritarian Personality. New York, Norton.

Akçam, T. (2004). From Empire to Republic. Turkish Nationalism and the Armenian Genocide. London, Zed Books.

Appleyard, K., Egeland, B., Van Dulmen, M., and Sroufe A. (2005). When more is not better: the role of cumulative risk in child behavior outcome. J. Child Psychol. 3, 235-245.

Barbaree, H. (1993). Denial and minimization among juvenile sex offenders. In The Juvenile Sex Offender, $\mathrm{H}$. Barbaree, ed (New York, NY, Guilford Press), pp. 246-249.

Bartov, O. (1991). The distortion of reality. In Hitler's Army. Soldiers, Nazis and War in the Third Reich, O. Bartov, ed (Oxford, Oxford University Press), pp. 106-178.

Browning, C. (1992). Ordinary Men. Reserve Police Battalion 101 and the Final Solution in Poland. New York, HarperCollins.

Burrin, P. (1994). Hitler and the Jews. London, E. Arnold.

Cleckley, H. (1988). The Mask of Sanity. Augusta, Emily Cleckley.

Cotter, P. (2006). Nazisme, terrorisme et tueurs en série. L'énigme de la violence extrême. Genève, Eclectica.

Cotter, P. (2007). Nazism, Terrorism and Serial Killers. Evil Unmasked. Geneva, Eclectica. (translation: Helen Mistry, London).

Cotter, P., and Holleufer, G. (2008). La vengeance des humiliés. Les révoltes du 21 e siècle. Genève, Eclectica.

Douglas, J., and Olshaker, M. (1999). The Anatomy of Motive. New York, Drew \& Scribner.

Friedländer,K. (1947). Analysis of environmental factors. In The Psychoanalytical Approach to Juvenile Delinquency, K.
Friedländer, ed (London, Paul Kegan), pp. 95-109.

Friedländer, S. (1978). History and Psychoanalysis. An Inquiry into the Possibilities and Limits of Psychohistory. New York, Holmes \& Meier.

Fromm, E. (1991). The Fear of Freedom. London, Routledge.

Gilligan, J. (2001). Preventing Violence. New York, Thames \& Hudson.

Hare, R. (1991). The Hare psychopathy checklist-revised. Toronto, MultiHealth System.

Hare, R., Forth, A., and Strachan, K. (1992). Psychopathy and crime across the life span. In Aggression and Violence Throughout the Life Span, R. Peters, R. McMahon, V. Quinsey, eds (London: Sage Publications), pp. 285-300.

Hazelwood, R., and Douglas J. (1980). The lust murderer. FBI Law Enforc. Bull. (4), 18-22.

Hirigoyen, M. F. (2000). Staking the Soul. Emotional Abuse and the Erosion of Identity. New York, Helen Marx Books.

Hitler, A. (1933). Mein Kampf. München, F. Eher Verlag, p. 355.

Human Rights Watch. (1999). Leave None to Tell the Story. Genocide in Rwanda. New York, Human Rights Watch.

Jäckel, E. (1972). Hitler's Weltanschauung. A Blueprint for Power. Middletown, CO, Wesleyan University Press.

Jaffé, P. D. (2008). Préambule. In La vengeance des humiliés. Les révoltes du $21 \mathrm{e}$ siècle, P. Cotter, G. Holleufer, eds (Genève: Eclectica), pp. 9-14.

Keppel, R., and Birnes W. (1995). The Riverman. Ted Bundy and I Hunt for the Green River Killer. New York, Pocket Books.

Kershaw, I. (1987). The Hitler Myth. Image and Reality in the Third Reich. Oxford, Oxford University Press.

Kiernan, B. (2002). The Pol Pot Regime. Race, Power and Genocide in

to identify multiple risk situations and intervene before the groups concerned experience widespread emotional distress. The aim of this method, preventive resilience, is to bolster the constructive capabilities of the discontented masses while at the same time removing the temptation of an opportunistic alliance with fanatics (Cotter and Holleufer, 2008).

\section{ACKNOWLEDGMENTS}

Geneva International Academic Network (Randall Harbour), Gilbert Holleufer and the International Committee of the Red Cross, Philip D. Jaffé, Daniel Warner, Jeff Crisp, Estelle Gitta (editor), Helen Mistry (translation).

Cambodia under the Khmer Rouge, 1975-1979. New York, Yale University Press.

King, M. L. (1986). A Testament of Hope. The Essential Writings of Martin Luther King. San Francisco, Harper \& Row.

Klein M. (1992). Notes on some schizoid mechanisms. In Envy and Gratitude and Other Works, 1946-1963, M. Klein, ed (London: Karnac Books), pp. 1-24.

Kogon, E. (2006). The Theory and Practice of Hell. The German Concentrations Camps and the System Behind Them. New York, Farrar, Straus \& Giroux.

Marshall, W. (1999). Diagnosing and treating sexual offenders. In The Handbook of Forensic Psychology, A. Hess, I. Weiner, eds. (New York: John Wiley), pp. 646-647.

Moffit, T. (1993). Adolescence-limited and life-course persistent anti-social behaviour: a developmental taxonomy. Psychol. Rev. 100, 674-701.

Moïsi, D. (2007). The clash of emotions. Fear, humiliation, hope and the world order. Foreign Affairs, 1, 8-12.

Mosse, G. (1990). The brutalization of German politics. In Fallen Soldiers. Reshaping the Memory of the World Wars, G. Mosse, ed (Oxford: Oxford University Press), pp. 159-180.

Negrao, C., Bonanno, G., Noll, J., Putnam, F., and Trickett, P. (2008). Shame, humiliation, and childhood sexual abuse. Distinct contributions and emotional coherence. Child Maltreat. 4, 350-363.

Ressler, R., Burgess, A., and Douglas, J. (1992). Sexual Homocide. Patterns and Motives. New York, Free Press.

Ressler, R., Schachtman, T. (1992). Whoever Fights Monsters. New York, Simon \& Schuster.

Rutter, M. (1990). Psychosocial resilience and protective mechanisms.
In Risk and Protective Factors in the Development of Psychopathology, J. Rolf, A. Masten, D. Cicchetti, K. Nuechterlein, S. Weintraub, eds, Cambridge, Cambridge University Press, pp. 181-214.

Samenow, S. (1984). Inside the Criminal Mind. New York, Times Books.

Speer, A. (1969). Erinnerungen. Berlin, Propyläen Verlag.

Staub, E. (1989). The Roots of Evil. The Origins of Genocide and Other Group Violence. Cambridge, Cambridge University Press.

Suedfeld, P., and Landon, B., (1978). Approaches to treatment. In Psychotic Behaviour.Approaches to Research, R. Hare, D. Schalling, eds. (Chichester: John Wiley), pp. 347-376.

Suny, R. G. (1997). Stalin and his stalinism. In Stalinism and Nazism. Dictatorships in Comparison, I. Kershaw, M. Lewin, eds (Cambridge: Cambridge University Press), pp. 26-52.

Tajfel H. (1969). Cognitive aspects of prejudice. J. Soc. Issues 25, 79-97.

Conflict of Interest Statement: Author declares that the research was conducted in the absence of any commercial or financial relationships that could be construed as a potential conflict of interest.

Received: 25 May 2009; paper pending published: 07 July 2009; accepted: 24 December 2009; published online: 18 January 2010.

Citation: Cotter P (2010) The path to extreme violence: Nazism and serial killers. Front. Behav. Neurosci. 3:61. doi: 10.3389/neuro.08.061.2009

Copyright (c) 2010 Cotter. This is an openaccess article subject to an exclusive license agreement between the authors and the Frontiers Research Foundation, which permits unrestricted use, distribution, and reproduction in any medium, provided the original authors and source are credited. 